\title{
THE MALL AS A PUBLIC SPACE The Case of La Florida, Santiago \\ The Mall as a Public Space: The Case of La Florida, Santiago
}

\author{
Flores Castillo, Mónica Andrea \\ (Observatorio de Ciudades UC, Instituto de Estudios Urbanos, Pontificia Universidad Católica de Chile) \\ maflore1@uc.cl
}

\section{RESUMEN}

La Florida, en Santiago de Chile, es un barrio de "clase media emergente" que ha crecido rápidamente durante los últimos años. Actualmente, es dentro del Mall donde sucede la mayor parte de la "vida pública", recreación y ocio de los residentes de La Florida, quienes son particularmente atraídos por este espacio público de consumo. Este fenómeno se vuelve visible al comparar los [verdaderos] espacios públicos en La Floridacalles, veredas, plazas y parques_con el espacio público ficticio del mall. Dentro del Mall todo está limpio y lleno de vida, sin embargo, inmediatamente fuera del Mall, las calles de La Florida están deficientemente mantenidas y carecen de vida pública. Más aún, existen dinámicas de clase e identidad social detrás de este fenómeno. Este paper apunta a esbozar una teoría que responda la siguiente pregunta: ¿Por qué es el Mall el espacio [privado de uso] público más exitoso en La Florida?

Palabras clave: Espacio Privado de Uso Público, Mall en Latinoamérica, Sociedad Neoliberal, Clases Sociales y Espacio Público.

Bloque temático: Espacio público y proyecto urbano en la metrópolis contemporánea.

\begin{abstract}
La Florida, in Santiago de Chile, is an "emergent middle class" neighborhood and is one of the fastest-densifying areas in Santiago. Currently, most "public life" and leisure time of La Florida's citizens happens in the Mall. People of La Florida are deeply attracted to this public space of consumption. This phenomenon becomes visible when comparing the physical quality of the [actual] public spaces of the neighborhood-the streets, sidewalks, plazas and parks - with this fictitious public space: the privately owned streets of the mall. Inside the Mall, everything is clean and full of life. However, immediately outside the Mall, La Florida streets are in poor condition, and lack of public life. Moreover, there are certain class and social identity dynamics behind this phenomenon. This paper aims to outline a theory answering the following question: why is the mall the most successful [privately owned] public space in La Florida?
\end{abstract}

Keywords: Privately Owned Public Space, The Mall in Latin America, Neoliberal Society, Social Class and Public Space

Topic: Public space and urban project in contemporary metropolis 


\section{Introduction}

La Florida, in Santiago de Chile, has historically been a working class residential neighborhood. Nowadays, La Florida is an "emergent middle class" neighborhood and is one of the fastest-densifying areas in Santiago. Its initially peripheral location has become a relatively central location due to better connectivity with the arrival of the Metro line 5 in 1997, the Metro line 4 in 2006, and the opening of the Vespucio Sur elevated freeway in 2005. Not only has transportation infrastructure increased in La Florida in the last 20 years, but also the Mall Plaza Vespucio was built in 1990 at the most important intersection of the neighborhood, Av. Americo Vespucio at Vicuña Mackenna. This mall occupies the most extensive area in Santiago, compared to other malls, with roughly 250,000 square meters dedicated to the structure alone. Years later, in 2003, Mall Florida Center was built in the neighborhood as well, about two kilometers away from Mall Plaza.

Currently, most "public life" and leisure time of La Florida's citizens happens in the Mall. People of La Florida are deeply attracted to this "public space of consumption", as Margaret Kohn (2004), inspired by Lefebvre's (1968), would call it. This phenomenon becomes visible in comparing the physical quality of the "actual public" space of the neighborhood-the street-with this fictitious public space: the privately-owned streets of the mall. Inside the mall everything is clean, and is full of life, commerce, bars and restaurants. However, immediately outside the Mall, La Florida streets are in poor condition and dirty, and the main commercial use are small industrial workshops. As an observer, I noticed as well how people walk and act in a more relaxed manner inside the Mall than outside in the streets of La Florida.

This paper aims to outline a theory answering the following question: why is the mall the most successful [privately-owned] public space in La Florida? Although there are visual differences in comparing the physical environment inside and outside the mall. I hypothesize that invisible social patterns are also driving the success of the mall, especially among middle classes, as a place for recreation. These patterns are related to the sense of social belonging and class enforcement, accompanied by a higher acquisition power and debt dynamics, due the neoliberalization process that happened in Chile during the late 1970's and 1980's.

\section{The origins of the Mall}

The Mall, as conceived by Victor Gruen — the architect to whom the creation of the mall is attributed to — was going to be the agora for the postwar modern era, an era in which the popularization of the automobile, and the migration to the suburbs were defining a new kind of citizen. Gruen saw in the 1950s American suburbs a lack of physical space for the public realm. So, he developed a new typology of shopping center, intended for the suburban dwellers to have a marketplace that, at the same time, would provide a space in which to satisfy their "civic needs", just as the ancient Greek agora did (Gruen and Smith, 1960). The mall envisioned by Gruen was the new public space of the suburbs, with plazas filled with fountains, exotic plants and entertainment (Figure 1) recreating downtown's public parks and plazas; a marketplace and a place in which to see and interact with other people in the suburbs.

Creative solutions and inventions proposed by Gruen such as climate control, indoor plazas and a food court, made it successfully replicable all over the States and later, all around the world. But among Victor Gruen's good intentions to make the suburbs more urban, what remained and spread was the soulless and profitable closed box off the highway (Baldauf \& Weingartner, 2002). 


\section{SIIU}

barcelona|santiago de chile junio 2019

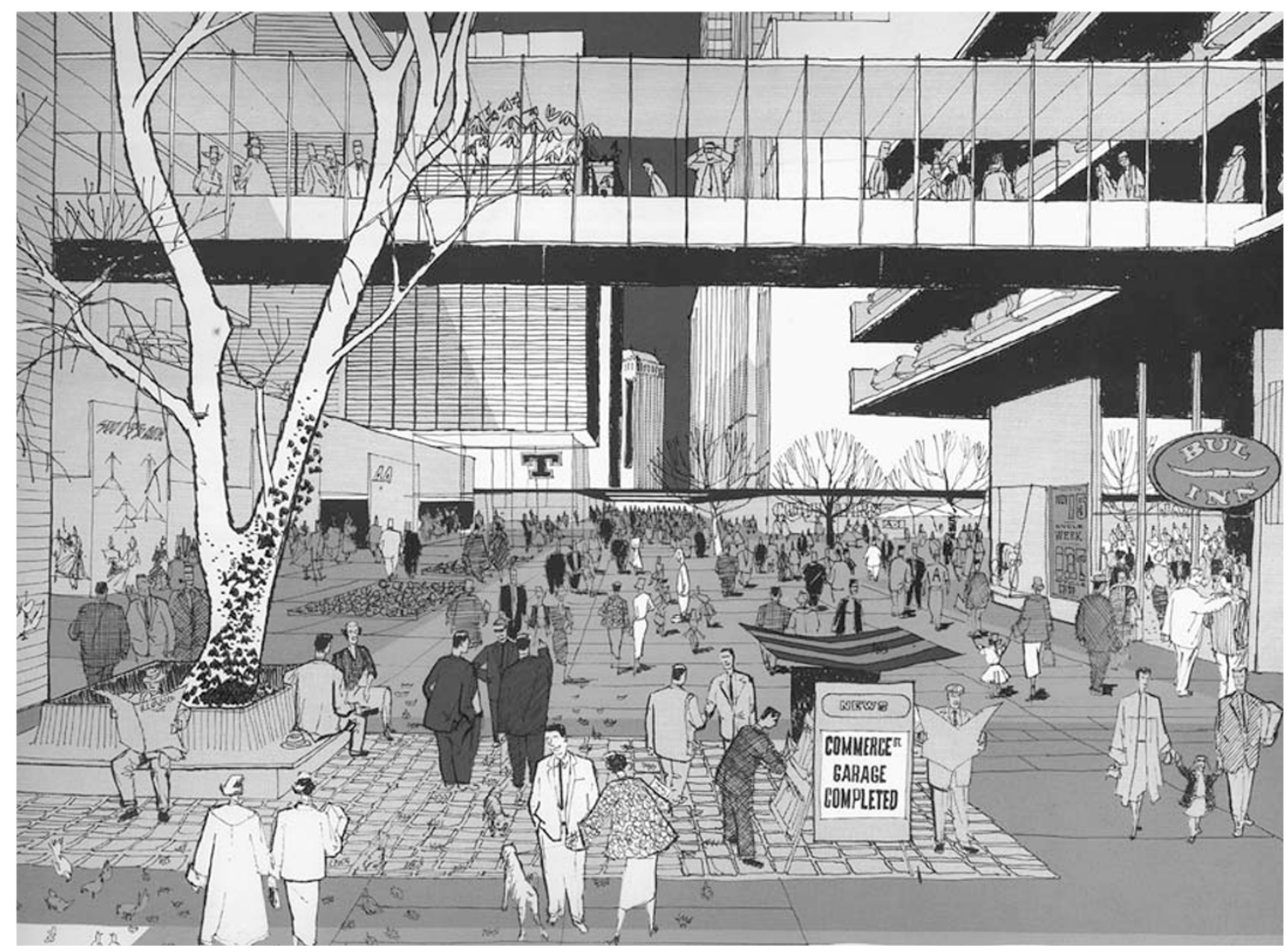

Figure 1: Forth Worth Plan. Victor Gruen Associates. Source: (Gruen \& Smith, 1960)

\section{The arrival of the mall to Chile}

At the apex of American mall development, the "classical typology" of the mall arrived in 1982 to the wealthy neighborhood of Las Condes. It was located right next to Avenida Kennedy, which was, at the time, the only highway in the upper-class area of the city. Mall Parque Arauco was a success. With easy car accessibility and luscious indoor facilities, developers intended to attract the wealthiest Santiaguinos: upper class citizens that were already suburbanized (Salcedo \& De Simone, 2012: 53-55).

Eight years later, a second big-scale "classical" Mall was developed in Santiago: Mall Plaza Vespucio. Surprisingly, this second mall was not targeting the upper classes of Santiago. Located in La Florida, Mall Plaza Vespucio was geared toward the lower-middle-class citizens of Santiago. However, it had two main things in common with the wealthier Parque Arauco: it was located right next to a vehicular artery: Avenida Americo Vespucio-which soon became a highway-and it was also located in a low density, but consolidated, residential area of Santiago (Figure 2). What developers probably saw as the "Chilean version of the American suburb" (De Simone and Salcedo, 2012). 


\section{$10 \begin{aligned} & \text { seminario } \\ & \text { internacional } \\ & \text { de investigación } \\ & \text { en urbanismo }\end{aligned}$}

barcelona|santiago de chile junio 2019

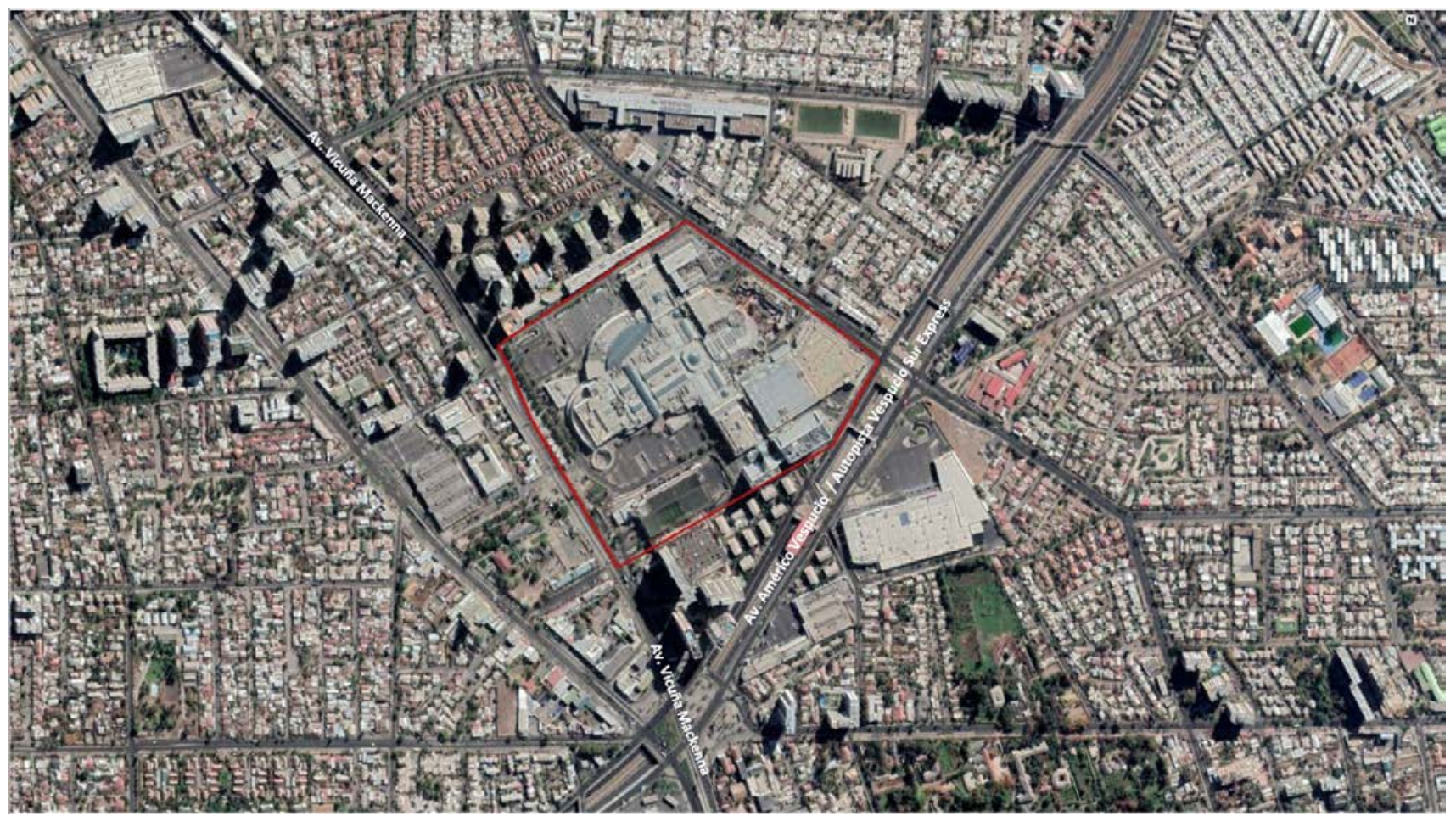

Figure 2: Aerial View of Mall Plaza Vespucio (red contour) and surroundings. Source: Google Earth.

\subsection{Neoliberalism and the shock therapy}

According to Liliana De Simone (2016), the shopping mall is an "artifact of globalization" (De Mattos, 2010) because it supplies goods and services freely tradable at a transnational level for which the mall acts as marketplace. This was especially relevant in the 80's and early 90's Santiago, in which downtown commerce provided mainly local goods. To understand the phenomena of the success of the shopping mall in Chile, especially among the middle classes, we must look at the neoliberalization process that took place in Chile during the military dictatorship from 1973 to 1990. De Simone (2016) claims that the neoliberal policies adopted during the dictatorship in the 80's led to the privatization of urban spaces, transformed the meaning of the public realm and established a commodification of everyday life in Chilean cities.

In 1956, in the midst of the Cold War, the Pontificia Universidad Catolica de Chile's School of Economics signed an agreement with the University of Chicago in order to send outstanding young Chilean students to pursue their graduate studies with professor Milton Friedman. The agreement included funding from the U.S. Department of State. Soon enough, 25 Chilean economists known as the "Chicago Boys" came back to Chile aiming to change the 1960s Chilean socialist economic system toward neoliberalism. Furthermore, after the 1973 coup d'état, the new dictator Augusto Pinochet, asked Milton Friedman for advice to solve high inflation and other economic difficulties (Figure 3). Friedman recommended what he called a "shock therapy": measures that would cause a high destabilization to Chilean society, but would increase Chilean Gross Domestic Product (GDP) in the long run. Specific measures included eliminating import barriers, cutting government expenditures, selling and privatizing the remaining Chilean state companies, and eliminating public housing and social security systems (Klein, 2007). Chile quickly adopted the policies proposed by Friedman and the Chicago Boys. The immediate consequences were bad: a family with an average salary had to expend $75 \%$ of its income in bread, and articles such as bus tickets and milk became luxury items (Whitecross, Winterbottom \& Klein, 2009). These policies succeeded in making the rich richer and the poor poorer, and they were enforced by oppressing whomever disagreed with them. With the excuse of calling them "the Marxist enemy" Pinochet government 
kidnapped, tortured, murdered and "disappeared" over 35,000 Chileans, while exiled more than 200,000 people (Informe Rettig, 1990). By massively violating human rights, Pinochet imposed Friedman's "shock therapy" and Chile became the first country to adopt Friedman's neoliberal system.

Pinochet's regime caused the loss of community identity among Chileans, a product of the high repression and severe punishment of any form of community gathering, manifestation or protest. As a proper shock therapy (Klein, 2007), the dictatorship was able to erase the identity and cohesiveness especially among the oppressed: the working and middle classes in Chile.

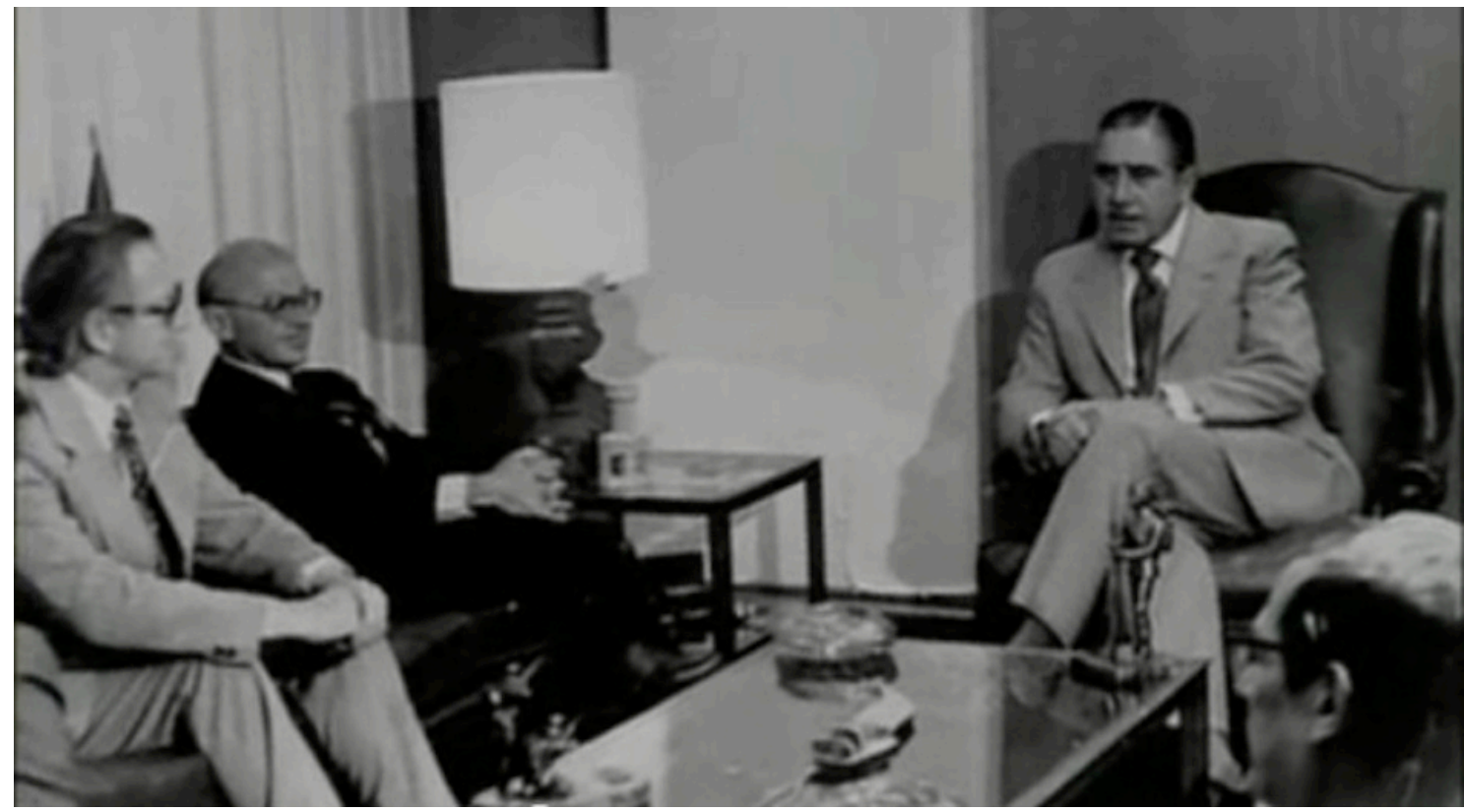

Figure 3: Pinochet meets Milton Friedman. Source: The shock doctrine, documentary.

\subsection{A new middle class: the rise of its purchasing power and the mall}

In the period from 1990 to 2000 -after returning to democracy — there was a steady economic growth: the GDP per capita increased from $\$ 2,204$ to $\$ 4,944$ USD. The unemployment rate went from $13 \%$ to $7.2 \%$ and the rate of people under the poverty line diminished from $38.6 \%$ to an $18 \%$. A new middle class had emerged.

As in many other countries in Latin America, this clase media emergente (emergent middle-class) was more vulnerable to poverty and more in debt than traditional and American middle class (Dávila, 2016). This new middle class was very different from the traditional middle class of the early $20^{\text {th }}$ century. From 1920 to 1970 Chilean middle class supported a national dream based in a strong community identity, democracy and social progress framed in urban growth, expansion of formal schooling and formalization of employment conditions and workers' rights (Espinoza \& Barozet, 2008) (Figure 4). As defined by Espinoza and Barozet (2008), today's Chilean middle classes, without being rich or poor, rely on their personal effort and education to remain in their social class. Nevertheless, they do not seem to achieve stability in their position. Subject to high levels of precariousness and with limited social protection, they inserted in Chilean social hierarchy without a clear identity and without a clear sense of how they were similar or different from other social groups. 


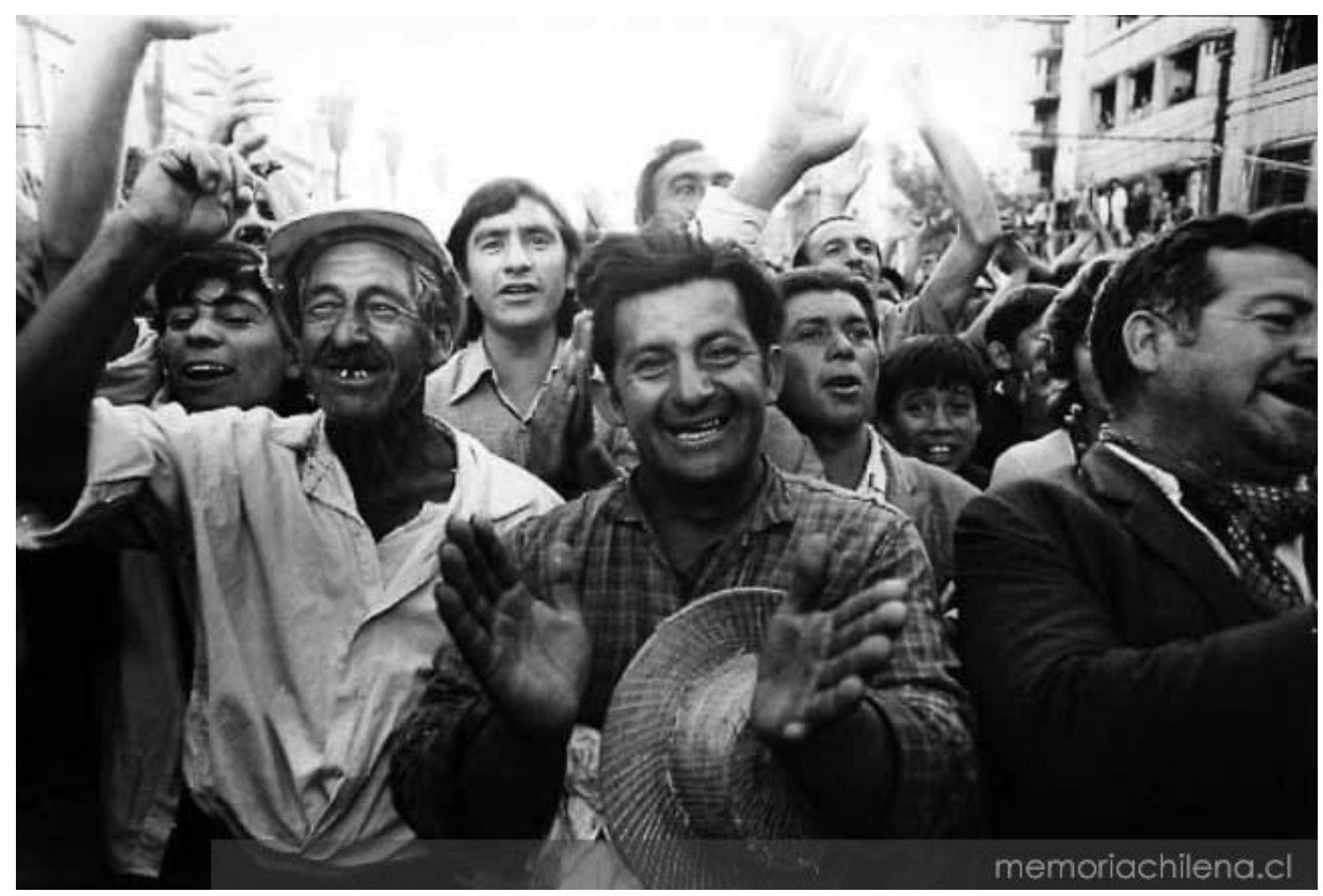

Figure 4: Chilean middle and working class citizens in a political manifestation. Source: Memoria Chilena.

Consumption power - and thus the success of the mall — is limited by personal income, especially among the most vulnerable classes. However, the arrival of the mall in Chile came hand in hand with the credit card, offering broad access to credit with few prerequisites and giving customers the illusion of unlimited purchasing power. Is not by chance that the first credit card in Chile was borne along with mega-retail. Issued in 1982, Fallabella's CMR card intended to give credit to buy in its store, a strategy that was quickly adopted by many other retail stores. According to De Simone and Salcedo (2012), the combination of economic growth, stability and credit access generated the optimal conditions for the rise of the shopping mall in Chile. These same factors, in addition to the above-mentioned changes in labor markets and production structures, explain the development of Chilean clase media emergente.

The drastic social-economic transformations that the country experienced over the decades of the 1970s and 1980s led to two main consequences that are key to understanding today's Chilean middle class. (1) A higher consumption power and general access to credit; and (2) what is more significant, the loss of collective identity among the middle classes in Chile. The dictatorship introduced the main idea of neoliberalism, in which every achievement and progress is solely the product of individual effort: the strongest wins, the weakest fails. This is the context within the mall arises in the middle-class areas of Santiago.

The mall came to Chile representing a physical space in which citizens, especially the new middle-class, could search for an identity. An identity based in the goods they choose to consume, and encouraged by the illusory power of credit. Foreign brands of clothing, technology, home supplies and fast food came to the country gathered under the figure of the mall: a modern, bright and clean "artifact of globalization" (De Simone, 2016; De Mattos, 2010), surprising and fascinating the middle-class. 


\section{La Florida: the municipality and the neighbors}

"The mall was bright, clean, and modern-everything we were not."

Dávila, Arlene (2016)

La Florida is an iconic neighborhood that represents the so-called clase media emergente (Dávila, 2016). Only from 2011 to 2013 its population under the poverty line has diminished from 12\% to 7\%, and according to Adimark's social sectors classification by consumption power $^{1}$, a $52 \%$ of the population belongs to the middle class (C2 and C3 groups) and a 12\% belongs to upper class (ABC1). However, there is a large rate of La Florida citizens who are qualified as poor by consumption power: $37 \%$ of La Florida citizens are classified in groups $D$ and $\mathrm{E}$. The mix of socioeconomic groups shows the diversity, as well as the vulnerability of its residents. In this social environment, the mall serves as the physical space of class differentiation and as a place to express one's acquisition power. The mall in La Florida becomes a place to watch and be watched shopping, a manifestation of class and status within the new middle class dynamics.

Given the proximity to subway stations, both Mall Florida Center and Mall Plaza Vespucio are located in the most pedestrian areas of La Florida. However, the cleanliness and liveliness of La Florida's Malls stand in contrast to the quality of its surrounding public spaces, and to the lack of public activity in them (Figures 5 and 6). Elevated highways, lack of maintenance and cleanliness of sidewalks and the abundance of small industrial businesses make La Florida's public spaces not very welcoming. Moreover, La Florida has a rate of only $3 \mathrm{~m}^{2}$ of park area per inhabitant, lower than Santiago's rate of $3.6 \mathrm{~m}^{2} / \mathrm{inh}$ abitant, and far from the $9 \mathrm{~m}^{2} /$ inhabitant recommended by the World Health Organization. La Florida's rate is striking when compared to Providencia's $13.8 \mathrm{~m}^{2} /$ inhabitant-a neighborhood in which traditional public spaces (parks, plazas and the streets) are more successful in terms of visits than the mall. Moreover, 53\% of La Florida neighbors recall that they do not use parks and plazas, whereas in Providencia only $18 \%$ of the neighbors recall not using them (Encuesta de Percepción de Calidad de Vida Urbana, 2015).

According to the Indicador de Calidad de Vida Urbana (2016) -that measures life quality ${ }^{2}$ across 93 municipalities in Chile — La Florida ranks very low: 73th among the 93 municipalities measured. With an index of 35.7, La Florida is below the national average of 42.3 and far away from Providencia, which is in the 3rd place of the ranking with an index of 67.4. La Florida is particularly low qualified in the category "housing and built environment" ${ }^{3}$ with an index of 28.7 whereas Providencia's index in that category is 63.4 and the Chilean average is 36.4 . This reflects not only La Florida's lack of good-quality public spaces, but also the vulnerability of its neighbors as reflected by their housing conditions.

Moreover, according to the Encuesta de Percepción de Calidad de Vida Urbana (2015), La Florida's neighbors are not satisfied with the quality of their environment. The survey shows discontent with street maintenance: a $49 \%$ of the residents in La Florida considered this as an issue, whereas in Providencia only a $7 \%$ of the residents did. Only a $42 \%$ of the neighbors of La Florida's residents are satisfied with the quality of public space in the municipality, a very low rate compared with $83 \%$ of Providencia. Within the same survey, under the Perception of the Neighborhood item, ${ }^{4}$ only $65 \%$ of the neighbors are satisfied with the cleanliness of La Florida whereas 95\% are satisfied in Providencia. Furthermore, only 30\% of La Florida's neighbors are satisfied with the safety in terms of crime, whereas in Providencia the satisfaction level is $65 \%$. Noticeably, neighbors of La Florida feel

\footnotetext{
${ }^{1}$ Adimark's classification by consumption power is a matrix that takes into account two variables: education level from incomplete school to college degree and goods in the household as shower, fridge, microwave, cable TV,

2 According to the following six criteria: housing and built environment; health and environment; socio-cultural conditions; business environment; labor conditions; and connectivity and transportation

${ }^{3}$ It specifically measures housing quality; overcrowding level; and investment in public spaces.

4 The index perception of the neighborhood refers to the immediate surroundings of the people's home, within the municipality.
} 
vulnerable in terms of public space quality, cleanliness and safety, and they do not feel welcomed or safe in the public areas of their own neighborhood.

From the economic perspective of Galetovic, Poduje and Sanhueza (2009) one of the main reasons for the success of the mall in Chile is the fast increase on income, accompanied by an increase in demand of goods and services. They developed a study, showing the number of nearby households necessary for Santiago malls to afford to pay their fixed costs and break even. This number has diminished significantly in the period from 1992 to 2006 in every Mall in Chile due household's disposable income increase. The case of La Florida's Mall Plaza Vespucio has shown the biggest change. In 1992 Plaza Vespucio needed roughly 250,000 households around it in order to sell USD\$300 million and break even. In 2006, Plaza Vespucio needed less than 83,000 households around in order to have the same amount of sales. A higher acquisition power among middleclasses has guaranteed the commercial success of the mall. Furthermore, they say that the main advantage of the mall compared with the city itself, and the municipal governments, is that the mall has only one owner interested in increasing the value of his/her investment. Private management of the mall solves a series of control and organization issues, internalizing and taking advantage of positive externalities of agglomeration economies and scale economies. The success of the mall, they conclude, is due to the bad management of the alternative institution: the municipalities. Municipal management has been unable to solve the issues as cleanliness, maintenance and safeness that could cause the failure of a commercial area.

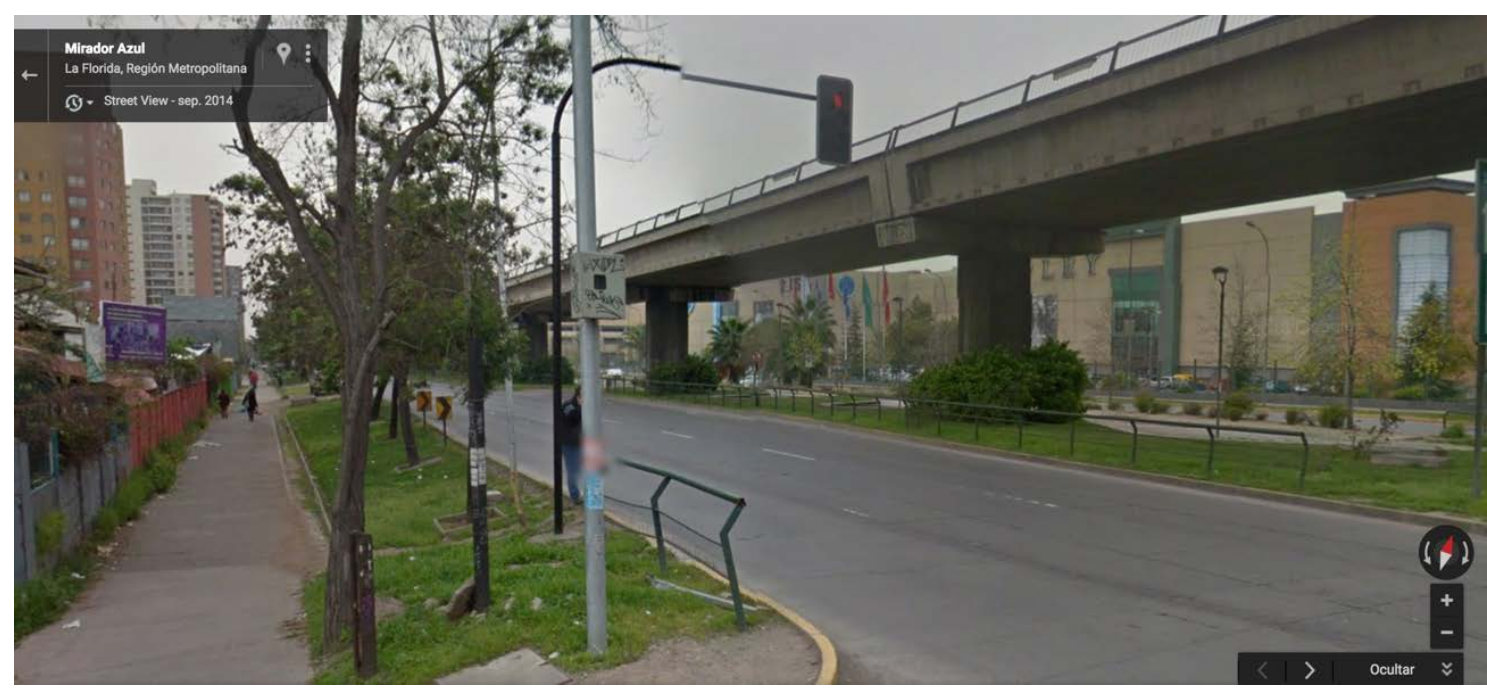

Figure 5: Streets of La Florida outside the mall. Source: Google Street View. 


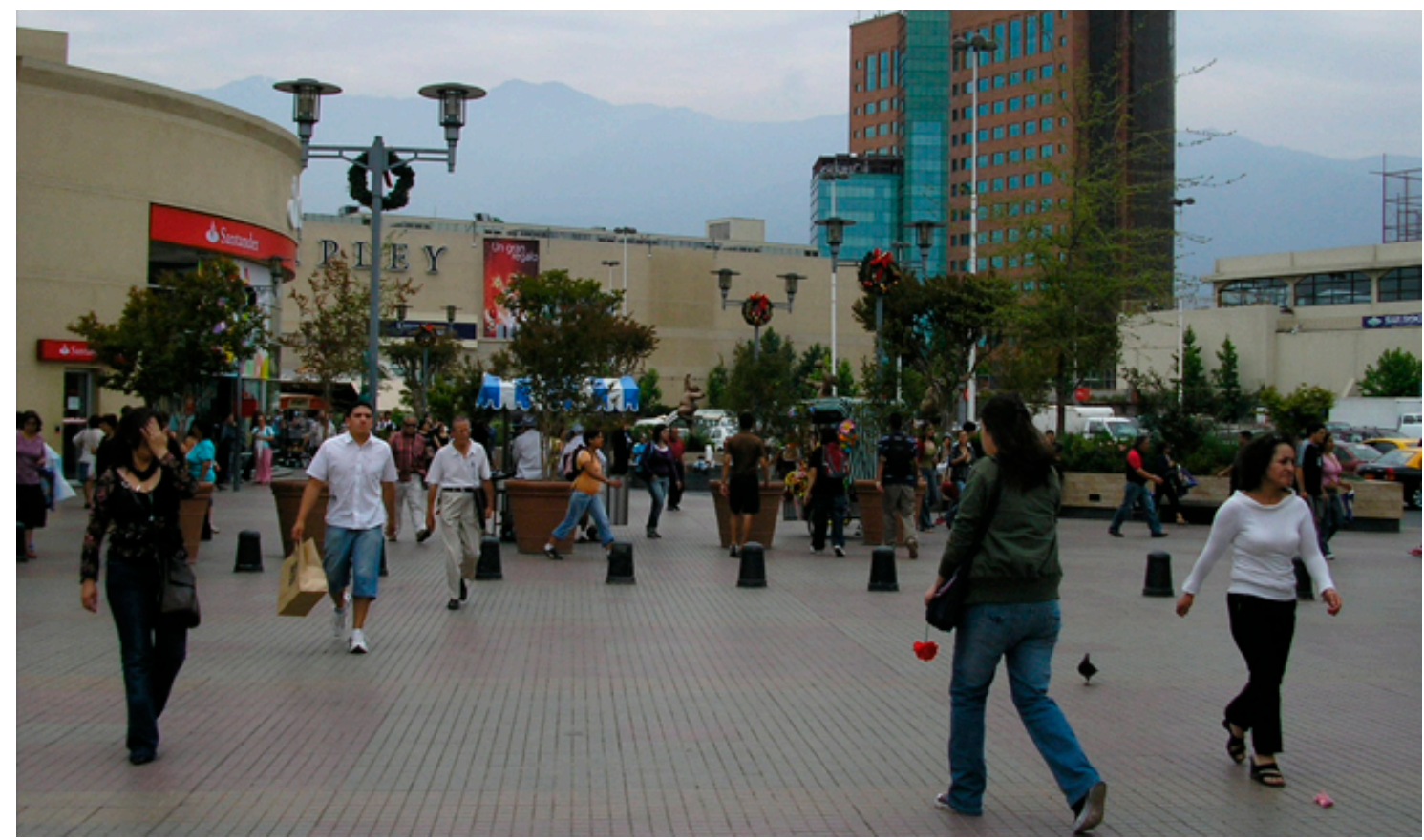

Figure 6: View of the pedestrian access to Mall Plaza Vespucio in La Florida. Source: Google Maps Photos

\section{The mall as a public space in La Florida}

The Mall in La Florida offers a place that is safe, clean and welcoming. There are not only retail stores and fast food, but also entertainment and cultural activities. Moreover, services such as postal service, health insurance, and banks have branch offices in Mall Plaza Vespucio. Even dermatological and dental clinics provide their services in the mall. As explained by Dávila (2016: 4) "shopping malls [in Latin America] are not merely offshoots of the emergence of an increase in new consumers. Instead, they are more fruitfully considered a primary medium helping to shape and bring new middle-class groups to light". As an instance, De Simone and Salcedo (2012) point out that the number of cinema spectators in Chile has increased from roughly 3 million in 1997 to 15 million in 2010, due to the incorporation of cinema halls within malls. The mall in the middle-class neighborhoods brings services closer and more accessible to the neighbors and acts, in many cases, as a culture driver. Consumers of these cultural services are probably people who might have never been to the cinema or to a theater play before the arrival of the mall. The mall acts as a multi-functional community center; in a way, the mall in La Florida has become the agora that Gruen intended for suburban America.

After performing qualitative studies in Mall Florida Center and Mall Plaza Vespucio, Salcedo and Stillerman (2010) note that visitors of La Florida's Malls use it as a space to build social relationships, as a place for game and as a context for activities that belong to other urban spaces. Moreover, they highlight the Mall in La Florida as a place where middle-class youth build their age and class identities, looking for a differentiation from adults and from youths from upper and lower social classes. They found out that La Florida residents appreciate Plaza Vespucio familiarity and proximity to their homes, and they feel comfortable interacting with friends, family and romantic partners in the mall. Salcedo and Stillerman also found that important cross-class encounters occur in the mall. Even though the mall is a private and exclusive space, the malls of La Florida ironically seem to be the most lively and diverse places in the neighborhood.

De Simone and Salcedo (2012:15) point out that "for many Latin-American citizens, the mall is a public space more open, free, complete and diverse than the 'truly' public spaces they have access to. That is why they inhabit the mall as they would inhabit a park or a plaza". They conclude that for them, the mall has become a "hyper-reality" of the public space —impressive, cleaner, safer and better- rather than a simulation of it. La 
Florida's neighbors use the mall as a place to gather, to see others, to build relationships, to entertain themselves, and to search for group identities. In La Florida, lack of good-quality public spaces and the perceived insecurity of the streets — due to the municipality's relatively low income and poor managementalong with the social discontent with these facts, have contributed to the success of the mall as a community center.

\section{The critique: Is the mall a Public Space?}

As used and enjoyed by the 3.8 million of monthly visitors (El Mercurio, 2014), Mall Plaza Vespucio is the main public space of La Florida. Still, is there something wrong with this? The mall in La Florida -and in other middleclass neighborhoods of Latin America - is placed in an area easily accessible by walking or public transportation. Therefore, it is more democratic and open than the American suburban mall (Salcedo, Stillerman, 2012). Then, how is the mall different from a traditional public space?

As the mall is a private space intended for public use, the owner of the mall has the unquestionable right to exclude according to his/her own criteria and rules, with the final intention of increasing sales and profit. (De Simone and Salcedo, 2012). Whereas in "truly" public spaces exclusion, if made, takes place under the authority of the government and the law, in its capacity as the legitimate embodiment of democratic will.

The mall as a public space is in some ways very inclusive. Advertisement and social activities organized by the mall aim to bring more people inside, claiming to be a free, open and popular space. The irony is that, at the same time, there are implicit rules of behavior and appearance that subtly provoke discomfort in those who are not able to meet them, usually being the most vulnerable ones. Moreover, these rules become explicit and enforced by guards who monitor behavior and are allowed to harass and expel those who do not meet them. The mall is an exclusive and exclusionary space: if anyone tries to dissent the social rules within the mall, he or she could be punished. That message is transmitted both by security guards and video cameras that silently keep the mall under control. Moreover, Salcedo and Stillman (2012) narrate an episode of a serious beating from security guards to a beggar in Plaza Vespucio's food court ${ }^{5}$. Likewise, under these exclusionary norms, political or community-engagement activities are left outside. Panhandling, sleeping or just eating "outside food" is repressible and punishable.

As Chilean middle classes are diverse and base their identity in their acquisition power (Espinoza \& Barozet, 2008), these "invisible barriers" act by excluding those that are not able to meet minimum standards of appearance and encouraging to those in the mall to keep improving their buena presencia by consuming in the mall (Dávila, 2016). As pointed out by De Simone and Salcedo (2012:32) "the mall includes anything that is valuable under the dominant codes and excludes everything that is not, or has lost its value under those codes (...) leaving out every person or activity that attempts against the capacity or desire of consumption of the mall's visitors".

\section{Conclusions}

"The cultural hegemony of the mall is so large that has educated the taste and preferences of the users, making it undistinguishable from the city that is supposed to mimic, and thus, becoming in fact the public plaza of our time".

\footnotetext{
${ }^{5}$ After the situation went public, the administration fired the responsible guards.
} 
Radical Neoliberal reforms enforced by Pinochet's regime led to a higher acquisition power and the formation of a new middle class. However, these economical changes were enforced through oppression and punishment of any form social gathering or manifestation. This severe repression led to erasing the collective identity that characterized mid-XX century's middle- and working-class. As a proper "shock therapy", it enforced a new idea of social behavior, the one behind the neoliberal system: to rely on each one's individual effort to progress amid society.

In La Florida, the mall offers a higher quality and safer environment than the one its residents could find in the "truly" public spaces they have access to. They can access activities, goods and services easily from their homes by using public transportation or just walking. In addition, they seem to act happily and spontaneously when they visit the mall with family and friends. Furthermore, in La Florida and other middle-class neighborhoods of Latin America, the mall actually became the agora that Victor Gruen dreamt about. The mall, for La Florida citizens, is the place in where they can meet, access culture and just watch other people in a safe environment. It is in fact a more democratic and open space than the one Gruen created: the Latin American mall is located within an urban context, easily accessible by public transportation. However, Gruen failed to anticipate that exclusionary rather than democratic patterns where going to prevail in the mall's social dynamics.

The exclusiveness of the mall is main reason why the mall is a successful place for the middle-class as opposed to the city's downtown: mall's popularity depends on its exclusionary patterns because it enforces class identity through differentiation from lower status citizens that do not meet the patterns to be accepted within the mall space. The mall is offering a place for building identities. However, these identities are based in consumption capacity and encouraged by the illusory power of credit. Therefore, the mall's social patterns force the users to expend and to fall into debt to reinforce their identity and their sense of belonging to a social group; this is the mall's paradox, hidden behind its modern, clean and exclusive environment.

These exclusion dynamics within the mall as a privately owned public space are successful among other middleclass neighborhoods and among upper-class suburban neighborhoods of Santiago. However, we can also see the opposite effect - the success and livelihood of "truly" public spaces - in other places in Santiago. As in the case of Providencia: this municipality is among the wealthier and better-equipped areas of Santiago, but unlike other wealthy neighborhoods of Santiago, is located right next to Santiago's downtown. Valuable to its inhabitants are aspects such as its central location, accessibility by public transport, diversity of commerce and jobs, cultural events offerings, and a varied bohemian scene. Providencia's urban - as opposed to suburbancharacteristics make it attractive to a special mix of residents: from young professionals to consecrated artists and from socialites to left-wing politicians. Aside having a higher municipality income to maintain them, public spaces are actually successful because Providencia's citizens look in them for a diversity that the exclusive and homogenizer space of a mall will ever provide.

The new middle-class citizens of La Florida have higher acquisition power and broader access to credit, but they are still vulnerable to poverty, to fell into debt and are less educated than inhabitants of historically wealthier neighborhoods, such as Providencia. In La Florida, the mall came to fill a void among its citizens: not only the lack of good quality public spaces, but also a void in terms of cultural and class identity.

\section{REFERENCES}

BALDAUF, A., \& WEINGARTNER, K. (2002). The Gruen Effect. Vienna, Austria: Pooldocks.

\section{DÁVILA, A. (2016). El mall: The spatial and class politics of shopping malls in Latin America. Univ of California Press.}

DE SIMONE, L. (2016). Arquitectura de consumo y Urbanismo de Retail: Construyendo la ciudad del consumo en Santiago de Chile. $V$ Coloquio Internacional sobre o comercio a cidade: uma relacao de origen. Sao Paulo, Brasil, 21-24 Marzo. 
DE MATTOS, C. A. (2010). Globalización y metamorfosis metropolitana en América Latina: de la ciudad a lo urbano generalizado. Revista de Geografía Norte Grande, (47), 81-104.

Encuesta de Percepción de Calidad de Vida Urbana. Ministerio de Vivienda y Urbanismo. (2015). Santiago de Chile. Retrieved from: http://calidaddevida.minvu.gob.cl/encuesta-de-percepcion-de-calidad-de-vida-urbana/ (Visited: 17/02/2019)

ESPINOZA, V., BAROZET, E. (2008) ¿De qué hablamos cuando decimos "clase media"? Perspectivas sobre el caso chileno. Expansiva, en foco (142). Santiago de Chile. Retrieved from: http://www.expansiva.cl/media/en foco/documentos/27082009115400.pdf (Visited: 17/02/2019)

FARÍAS, I. (2009). Intimidad cultural en espacios de consumo. El Plaza Vespucio y la imposibilidad de una cultura pública. In M. TIRONI RODÓ \& F. PÉREZ OYARZÚN. SCL: Espacios, prácticas y cultura urbana: (1629). Santiago de Chile: Ediciones ARQ.

GRUEN, V. \& SMITH, L. (1960) Shopping Towns USA: The planning of Shopping centers.

GAletOVIC, A., PODUJE, I., \& SANHUEZA, R. (2009). En Santiago De Centros Comerciales A Centros Urbanos. Revista Centro de Estudios Públicos 114. Santiago de Chile. Retrieved from: https://www.cepchile.cl/cep/site/artic/20160304/asocfile/20160304094959/rev114 completa.pdf (Visited: 17/02/2019)

Indicador de Calidad de Vida de Ciudades chilenas. Instituto de Estudios Urbanos. Pontificia Universidad Catolica de Chile. (2016) Santiago de Chile. Retrieved from: http://estudiosurbanos.uc.cl/images/noticiasactividades/2016/Mayo 2016/Presentacion ICVU 2016 VF web.pdf (Visited: 17/02/2019)

Informe del Estado del Medioambiente. Ministerio de Medio Ambiente. (2016). Santiago de Chile. Retrieved from http://sinia.mma.gob.cl/wp-content/uploads/2017/08/IEMA2016.pdf (Visited: 17/02/2019)

KHON, M. (2004). Brave New Neighborhoods. Routledge. New York, NY.

KLEIN, N. (2007) The Shock Doctrine: the rise of disaster capitalism. Metropolitan Books. New York, NY.

LEFEBVRE, H. (1968) "The Right to the City," Writings on Cities, trans. and eds. Eleonore Kofman and Elizabeth Lebas (Malden, Mass.: Blackwell, 1996; Le Droit à la ville orig. pub. 1968)

SALCEDO, R., \& DE SIMONE, L. (2012). Los malls en Chile: 30 años. Santiago de Chile: Uqbar Editores. Retrieved from:

https://www.researchgate.net/publication/277955596 El mall en Chile 30 anos (Visited 17/02/2019)

STILLERMAN, J. \& SALCEDO, R. (2012). Transposing the urban to the mall: routes, relationships, and resistance in two Santiago, Chile, shopping centers. Journal of Contemporary Ethnography 41, no. 3: 309336. Retrieved from: https://journals.sagepub.com/doi/abs/10.1177/0891241611434551 (Visited: 17/02/2019)

STILLERMAN, J. \& SALCEDO, R. (2010). Es mucho más que comprar... Discursos y prácticas espaciales cotidianas en Malls de Santiago. Estudios avanzados 13: 79-103. Retrieved from:

https://www.redalyc.org/pdf/4355/435541644005.pdf (Visited: 17/02/2019)

WHITECROSS, M., WINTERBOTTOM, M., KLEIN, N. (2009) The Shock Doctrine. UK: Renegade Pictures \& Revolution Films. 


\section{Online Sources}

Comisión de Verdad y Reconciliación de Chile. Informe Rettig. (1990) Santiago de Chile. Retrieved from: http://www.derechoshumanos.net/lesahumanidad/informes/informe-rettig.htm (Visited: 16/02/2019)

Mapa Socioeconómico de Chile. Adimark. Retrieved from:

http://www.adimark.cl/medios/estudios/informe mapa socioeconomico de chile.pdf (Visited: 17/02/2019) Memoria Chilena. El Gobierno de la Unidad Popular. Retrieved from:

http://www.memoriachilena.gob.cl/602/w3-article-31433.html\#imagenes (Visited: 17/02/2019)

Plaza Vespucio y Costanera Center lideran ranking de malls con más flujo de visitas. El Mercurio. (2014). Retrieved from: http://www.emol.com/noticias/economia/2014/11/28/692158/plaza-vespucio-y-costaneracenter-son-los-malls-con-mayor-flujo-de-visitas-en-la-rm.html (Visited: 17/02/2019) 